\title{
Filtration Rates of Juvenile Purple Clam, Saxidomus purpuratus (Sowerby) Feeding on Red Tide Dinoflagellates
}

\author{
Chang-Hoon Lee ${ }^{1}$, Seong-Dae Moon ${ }^{1,2}$ and Chan-Gyoung Sung ${ }^{1,3}$ \\ ${ }^{1}$ Institute of Environmental Protection and Safety, NeoEnBiz Co. Bucheon 420-806, Korea \\ ${ }^{2}$ Department of Biological Science, Chungnam National University, Daejon 305-764, Korea \\ ${ }^{3}$ Department of Energy and Environmental System Engineering, University of Seoul, Seoul 130-743, Korea
}

\begin{abstract}
The purpose of this study is to compare the clearance rate (CR) and intake rate (IR) of juvenile purple clam, Saxidomus purpuratus when feeding on different unialgal diet of red tide dinoflagellates (RTDs), and to know what is the most important cell characteristic of RTDs to cause the differences in feeding parameters. Experiments were performed to measure the $\mathrm{CR}$ and IR of juvenile $S$. purpuratus as a function of algal concentration when food was either the standard food, Isochrysis galbana or one of 9 RTDs.

Patterns of CR with increasing algal concentration were similar among different RTDs. The highest $C_{\max }$ was observed when S. purpuratus was feeding on A. affine, while the lowest on C. polykrikoides. The patterns of IR with increasing algal concentration were also similar among different RTDs. However, there were great differences in the maximum value of IR $\left(I_{\max }\right)$ among different RTDs. The highest $I_{\max }$ was observed when $S$. purpuratus was feeding on $A$. carterae, while the lowest on $G$. catenatum.

Some RTDs similar in size showed different $C_{\max }$. Other RTDs different in size showed similar $I_{\max }$. Life form of each RTD affected significantly the $I_{\max }$, which was higher for single-celled RTDs than chain-forming RTDs. There were no significant differences in feeding parameters between toxic and nontoxic RTDs. Moreover, a toxic dinoflagellate, $A$. carterae recorded the highest $I_{\max }$ among RTDs. The most important characteristic of RTD as a factor affecting the feeding rate of S. purpuratus was life form, not size or toxicity of RTD species.
\end{abstract}

Key Words: Saxidomus purpuratus, Red Tide, Dinoflagellates, Clearance rate, Intake rate

\section{INTRODUCTION}

The purple clam, Saxidomus purpuratus (Class Bivalvia, Family Veneridae) is a suspension-feeding bivalve and one of the most important food resources for human. Its natural distribution is restricted to the coasts of China, Japan, and Korea. It inhabits the soft bottoms with silty sand from intertidal to subtidal zones to a depth of ca. $20 \mathrm{~m}$ (Choe et al., 1999). Recently, commercial interest in this species has increased with strong demands and high prices. The

Received: December 5, 2012 ; Accepted: December 17, 2012

Corresponding author: Chang-Hoon Lee

Tel: +82 (32) 670-7210 e-mail: chlee@neoenbiz.com $1225-3480 / 24459$ commercial yields from the traditional exploitation by divers have been declining due to over-harvesting. Moreover, the main catch fields of this species often suffer from severe harmful algal blooms. The severity of algal blooms and the damages to coastal ecosystem are fluctuating. Most of marine harmful algal blooms (red tide) are dominated by dinoflagellates. Massive blooms of dinoflagellates have often caused large-scale mortalities of shellfishes in aquafarms (e.g. ECOHAB, 1995). Thus, there have been many studies on the effects of red tide dinoflagellates (RTDs) on shellfish populations (Widdows et al., 1979; Nielsen and Strømgren, 1991; Lesser and Shumway, 1993; Luckenbach et al., 1993; Matsuyama et al., 1997; Li et al., 2001; Lee, 2003; Lee et al., 2003). However, there are little studies on the interactions between dinoflagellates and commercially important bivalve 
species in Korea. Here, the purpose of this study was established to know how the feeding activities are affected when $S$. purpuratus is feeding on various species of RTDs (Akashiwo sanguinea, Alexandrium affine, Alexandrium catenella, Amphidinium carterae, Cochlodinium polykrikoides, Gymnodinium catenatum, Lingulodinium polyedrum, Prorocentrum minimum, Scrippsiella trochoidea). From laboratory experiments, clearance rates and intake rates of juvenile $S$. purpuratus were measured as functions of algal concentrations when clams were fed on either unialgal prey of the RTDs or a standard food (Isochrysis galbana). From the functional responses, feeding parameters were estimated and compared among different RTD species, and the effects of cell characteristics (size, life form, and toxicity) of RTDs on feeding parameters were discussed. The results of this study will provide the basic information on the physiological change of bivalves during outbreak of red tides.

\section{MATERIALS AND METHODS}

\section{Test Organisms}

The juvenile Saxidomus purpuratus were obtained from a cohort reared at ambient seawater temperature in the Taean Marine Hatchery, National Fisheries Research and Development Institute of Korea. Three months old juveniles of $S$. purpuratus (4-6 $\mathrm{mm}$ in shell length) were used in feeding experiments. Clams were acclimated to the experimental temperature for 4 weeks: they were transferred into a 10 -L aquarium with $5-\mu \mathrm{m}$ filtered seawater (salinity: $30 \mathrm{psu}$ ), then the aquarium was placed in an incubator (temperature: $20^{\circ} \mathrm{C}$ ) with 12 light: 12 dark cycle of $5 \mu \mathrm{E} / \mathrm{m}^{2} / \mathrm{sec}$ provided by cool-white fluorescent lights. During acclimation, seawater was fully renewed everyday and clams were fed $1.0 \times 10^{6}$ cells $/ \mathrm{mL}$ of Isochrysis galbana. Mortality was checked everyday and dead individuals were immediately removed when they were found. One day before the feeding experiments, clams were rinsed twice with freshly filtered seawater and depurated for $24 \mathrm{hr}$.

The red tide dinoflagellates (RTDs, Table 1) were grown at $20^{\circ} \mathrm{C}$ in enriched $\mathrm{f} / 2$ seawater medium (Guillard and Ryther, 1962) without silicate, with continuous illumination of $100 \mu \mathrm{E} / \mathrm{m}^{2} / \mathrm{sec}$ provided by cool-white fluorescent lights. Only cultures in exponential growth phase were used for experiments. Mean equivalent spherical diameter (ESD) of each alga was measured by a PAMAS-SVSS particle

Table 1. Size, carbon content, toxicity, life form, and the range of test concentration of the standard food (Isochrysis galbana) and the red tide dinoflagellates used in feeding experiments to measure clearance rate and intake rate of juvenile Saxidomus purpuratus. ESD: estimated spherical diameter. NT: nontoxic, T: toxic, $\mathrm{S}$ : single cell, $\mathrm{C}$ : chain form.

\begin{tabular}{lccccc}
\hline \multicolumn{1}{c}{ Species } & $\begin{array}{c}\text { ESD } \\
(\mu \mathrm{m})\end{array}$ & $\begin{array}{c}\text { Carbon } \\
(\mathrm{ngC} / \mathrm{cell})\end{array}$ & Toxicity & Form & $\begin{array}{c}\text { Test concentration } \\
(\text { cells/mL })\end{array}$ \\
\hline Isochrysis galbana & 4.5 & 0.02 & $\mathrm{NT}$ & $\mathrm{S}$ & $5.1 \times 10^{4}-2.7 \times 10^{6}$ \\
Akashiwo sanguinea & 36.3 & 2.23 & $\mathrm{NT}$ & $\mathrm{S}$ & $7.1 \times 10^{1}-2.9 \times 10^{3}$ \\
Alexandrium affine & 24.8 & 0.84 & $\mathrm{NT}$ & $\mathrm{C}$ & $7.4 \times 10^{1}-6.7 \times 10^{3}$ \\
Alexandrium catenella & 24.5 & 0.83 & $\mathrm{~T}$ & $\mathrm{C}$ & $6.7 \times 10^{1}-7.4 \times 10^{3}$ \\
Amphidinium carterae & 16.2 & 0.27 & $\mathrm{~T}$ & $\mathrm{~S}$ & $2.2 \times 10^{3}-1.3 \times 10^{5}$ \\
Cochlodinium polykrikoides & 23.2 & 0.70 & $\mathrm{NT}$ & $\mathrm{C}$ & $1.4 \times 10^{2}-2.4 \times 10^{3}$ \\
Gymnodinium catenatum & 34.0 & 1.88 & $\mathrm{~T}$ & $\mathrm{C}$ & $2.5 \times 10^{1}-1.2 \times 10^{3}$ \\
Lingulodinium polyedrum & 37.9 & 2.50 & $\mathrm{NT}$ & $\mathrm{S}$ & $1.3 \times 10^{2}-3.9 \times 10^{3}$ \\
Prorocentrum minimum & 12.9 & 0.15 & $\mathrm{NT}$ & $\mathrm{S}$ & $9.0 \times 10^{2}-5.3 \times 10^{4}$ \\
Scrippsiella trochoidea & 25.1 & 0.85 & $\mathrm{NT}$ & $\mathrm{S}$ & $3.7 \times 10^{2}-1.3 \times 10^{4}$ \\
\hline
\end{tabular}




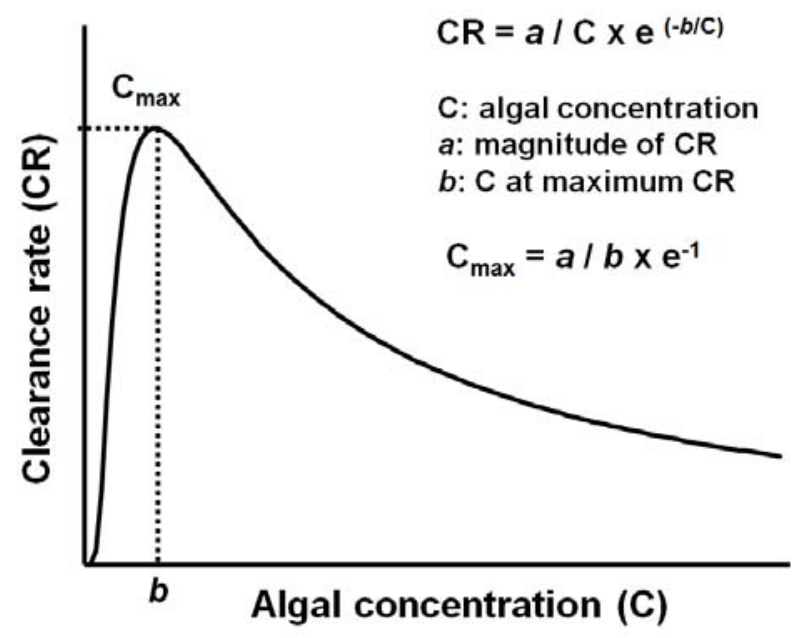

Fig. 1. The general relationship between algal concentration and clearance rate of bivalves expressed by an exponential equation (Riisgård, 1988)

counter. The number of measured cells was more than 2000. Cell volume $(\mathrm{V})$ was calculated as: $\mathrm{V}=4 / 3 \pi$ $(\mathrm{ESD} / 2)^{3}$. The carbon content was estimated from cell volume according to Strathmann (1967).

\section{Feeding Experiments}

Experiments were designed to determine the clearance rate (CR) and intake rate (IR) of $S$. purpuratus as a function of the algal concentration when clams were feeding on unialgal diet of either the standard food (I. galbana) or the RTD. The concentration range of each alga was determined from preliminary experiments so that the typical functional responses for both CR and IR could be obtained (Table 1). Three 100-mL polyethylene beakers for each concentration were used as experimental chambers. Algal suspensions with 6 different initial concentrations were prepared by diluting the dense cultures with filtered seawater to the target concentrations. Chambers were filled with $50 \mathrm{~mL}$ of algal suspensions, then, according to the concentration, 2 to 5 individuals of $S$. purpuratus were transferred into each chamber. Chambers were incubated in an undisturbed place at $20^{\circ} \mathrm{C}$ under $5 \mu$ $\mathrm{E} / \mathrm{m}^{2} / \mathrm{sec}$ of cool white fluorescent lights for 1 to $2 \mathrm{hr}$. To determine the actual concentrations of algae at the beginning and the end of experiments, 5 - $\mathrm{mL}$ aliquot of algal suspension was sub-sampled from each bottle and fixed with 5\% Lugol's solution, and all or more than 400 cells in triplicate 1-mL Sedgwick-Rafter chambers were counted. The algal concentration (in cells $/ \mathrm{mL}$ ) was converted to the carbon equivalent (in $\mathrm{mgC} / \mathrm{L}$ ) to facilitate inter-specific comparison of $\mathrm{CR}$ and IR among different algal species. The flesh dry weight (FDW) of $S$. purpuratus was determined by removing soft tissues from the shells, drying in an oven at $90^{\circ} \mathrm{C}$ for $48 \mathrm{hr}$, and then weighing on an electronic microbalance (Sartørius Co.) to the nearest $0.01 \mathrm{mg}$.

\section{Clearance rate and intake rate}

The clearance rate $(\mathrm{CR}, \mathrm{L} / \mathrm{g} / \mathrm{hr})$ was calculated using the equation of Coughlan (1969) as:

$$
\mathrm{CR}=\mathrm{V} \times \ln \left(\mathrm{C}_{0} / \mathrm{C}_{\mathrm{t}}\right) /(\mathrm{FDW} \times \mathrm{t})
$$

where $\mathrm{V}$ is the volume of algal suspension $(\mathrm{L}), \mathrm{C}_{0}$ is the initial concentration $(\mathrm{mgC} / \mathrm{L}), \mathrm{C}_{t}$ is the final concentration $(\mathrm{mgC} / \mathrm{L})$, FDW is the flesh dry weight of $S$. purpuratus ( $\mathrm{g}$ ), and $\mathrm{t}$ is the incubation time (hr). To determine the functional response of the CR of $S$. purpuratus to the algal concentration, the data were fitted to an exponential equation (Fig. 1) (Riisgård, 1988) as:

$$
\mathrm{CR}=\mathrm{a} / \mathrm{C}^{*} \times \mathrm{e}^{\left(-\mathrm{b} / \mathrm{C}^{*}\right)}
$$

where $\mathrm{C}^{*}$ is the mean algal concentration during incubation period (geometric mean of $\mathrm{C}_{0}$ and $\mathrm{C}_{\mathrm{t}}$ ) and the constants $\mathrm{a}$ and $\mathrm{b}$ are parameters estimated from curve-fitting. Parameter a explains the magnitude of the $\mathrm{CR}$ and parameter $\mathrm{b}$ denotes the algal concentration at which the $\mathrm{CR}$ is maximal. The maximum $\mathrm{CR}\left(\mathrm{C}_{\max }\right)$ was calculated by substituting algal concentration with estimated $b$ value to the above equation as:

$$
\mathrm{C}_{\max }=\mathrm{a} / \mathrm{b} \times \mathrm{e}^{-1}
$$

Since we did not measure the rate of pseudofeaces production, the intake rate $(\mathrm{IR}, \mathrm{mgC} / \mathrm{g} / \mathrm{hr}$ ) was 


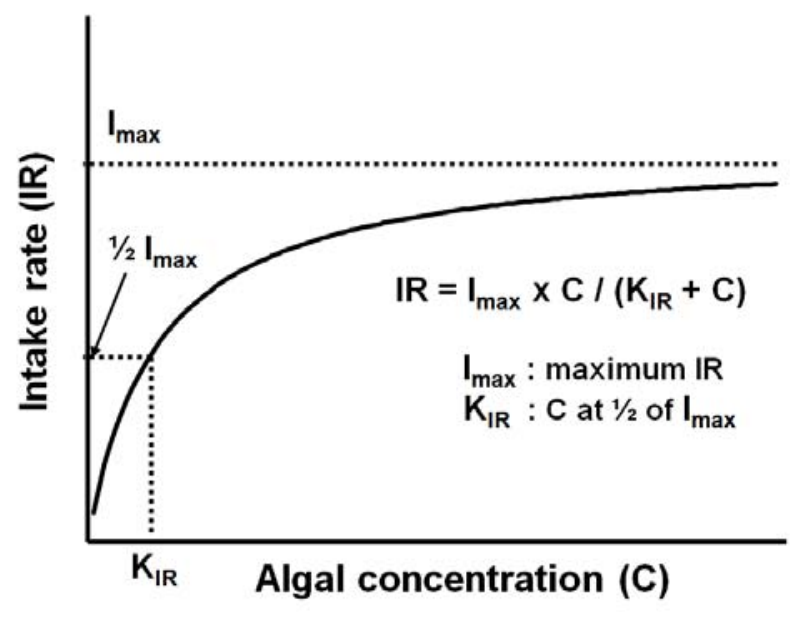

Fig. 2. The general relationship between algal concentration and intake rate of bivalves expressed by the Michaelis-Menten equation (Båmstedt et al., 2000)

calculated (Foster-Smith, 1975; Coutteau et al., 1994) instead of the ingestion rate as:

$$
\mathrm{IR}=\mathrm{C}^{*} \times \mathrm{CR}
$$

To determine the functional response of the IR of $S$. purpuratus to the algal concentration, the data were fitted to the Michaelis-Menten equation (Fig. 2) (Crawley, 1975; Båmstedt et al., 2000) as:

$$
\mathrm{IR}=\mathrm{I}_{\max } \times \mathrm{C}^{*} /\left(\mathrm{KIR}+\mathrm{C}^{*}\right)
$$

where $I_{\max }$ is asymptotic maximum $I R$ and $K_{I R}$ is the half-saturation constant, i.e. the algal concentration where IR $=I_{\max } / 2$.

\section{Statistical analyses}

The CR and the IR data among different algal concentrations of each RTD were compared by one-way analysis of variance (ANOVA) on SPSS program. Multiple comparisons were conducted using Tukey's HSD (Zar, 1984). Before the statistical analyses, the data were tested for normality and homogeneity of variance. If at least one of the above ANOVA requirements was not met, the data were $\log _{10}$ transformed, then ANOVA was repeated. For all ANOVA, a significance level of $\alpha=0.05$ was used.

\section{RESULTS AND DISCUSSION}

\section{Feeding rates on standard food}

Clearance rate (CR, mean \pm SD) of juvenile Saxidomus purpuratus when feeding on unialgal diet of the standard food (Isochrysis galbana) ranged from $1.7 \pm 0.3$ to $13.7 \pm 1.1 \mathrm{~L} / \mathrm{g} / \mathrm{hr}$ (Fig. 3A). Algal concentration affected significantly the CR $(\mathrm{F}=9.46$, $\mathrm{p}=0.001$ ). As algal concentration increased from 1.0 to $3.5 \mathrm{mgC} / \mathrm{L}$, the $\mathrm{CR}$ increased rapidly. But, after reaching the maximum, it decreased significantly as algal concentration increased from 3.5 to $15.9 \mathrm{mgC} / \mathrm{L}$ ( $\mathrm{p}=0.028$ ). It was lowest when algal concentration was highest. Reduction in clearance rate with increasing algal concentration is known as a general phenomenon (Bayne et al., 1976). Multiple comparison showed that there were no significant differences in CR when algal concentration was 15.6 to $54.6 \mathrm{mgC} / \mathrm{L}$ $(\mathrm{p}=0.478)$. When $\mathrm{CR}$ data were fitted to the equation (2), the maximum $\mathrm{CR}\left(\mathrm{C}_{\max }\right)$ was estimated as $15.2 \mathrm{~L} / \mathrm{g} / \mathrm{hr}$, which is in good accordance with Lee et al. (2002).

Intake rate (IR, mean \pm SD) of juvenile $S$. purpuratus when feeding on unialgal diet of the standard food (I. galbana) ranged from $9.4 \pm 2.2$ to $98.5 \pm 27.8 \mathrm{mgC} / \mathrm{g} / \mathrm{hr}$ (Fig. 3B). IR was also affected significantly by the algal concentration $(\mathrm{F}=14.88, \mathrm{p}$ $<0.001)$. It increased rapidly with increasing algal concentration from 1.0 to $8.0 \mathrm{mgC} / \mathrm{L}(\mathrm{p}=0.003)$. As algal concentration increased further, the IR was saturated and fluctuated between 90.2 and 98.5 $\mathrm{mgC} / \mathrm{g} / \mathrm{hr}$. There was no significant difference in IR when algal concentration was 8.0 to $54.6 \mathrm{mgC} / \mathrm{L}(\mathrm{p}=$ 0.424). When IR data were fitted to the equation (5), the maximum IR (Imax) was estimated as 108.1 $\mathrm{mgC} / \mathrm{g} / \mathrm{hr}$, which is also in good accordance with Lee et al. (2002).

\section{Feeding rates on red tide dinoflagellates}

In general, patterns of $\mathrm{CR}$ with increasing algal concentration for all of 9 RTDs were quite similar to that for the standard food (Fig. 4). CR increased rapidly at lower range of algal concentration, reached maximum, and then decreased gradually as algal 

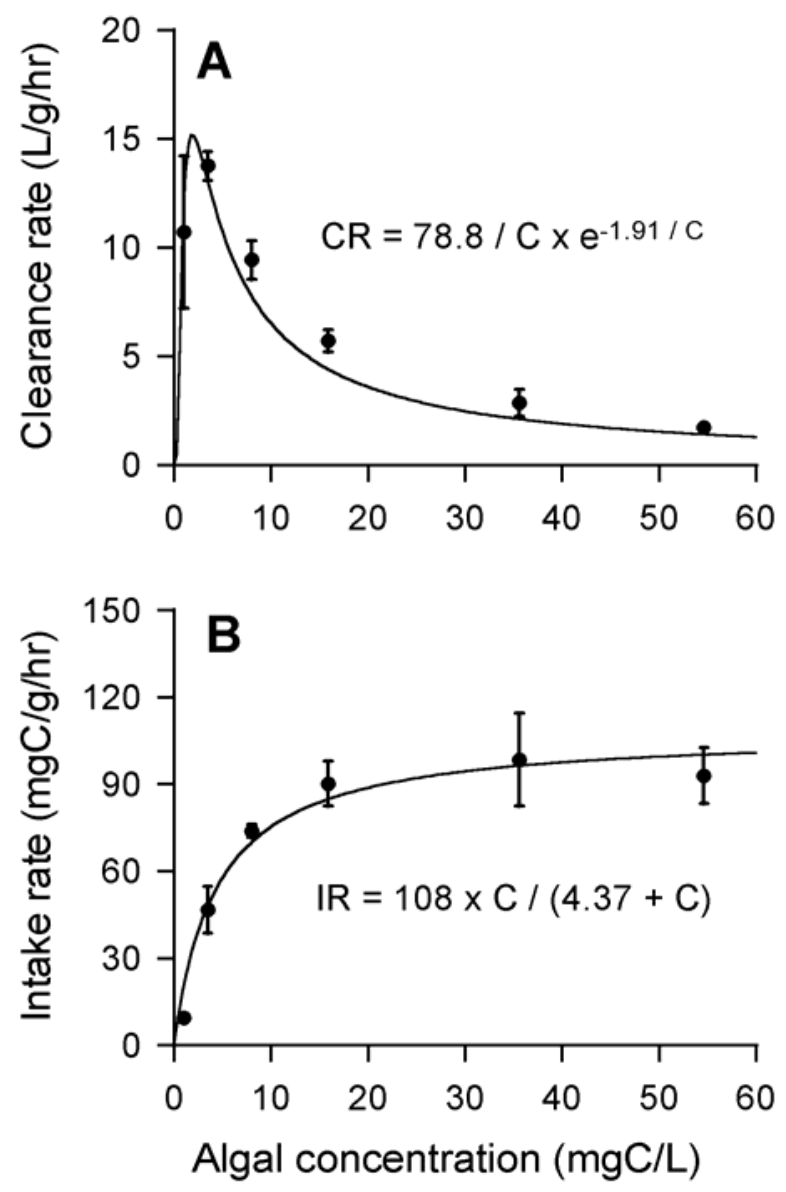

Fig. 3. Typical functional responses of juvenile Saxidomus purpuratus to algal concentration (C) when feeding on unialgal diet of standard food (Isochrysis galbana). A: clearance rate $(\mathrm{CR}), \mathbf{B}$ : intake rate (IR). Symbol represents treatment mean $\pm \mathrm{SE}$. CR data were fitted to an exponential equation [eq. (2)], and IR data were fitted to the Michaelis-Menten equation [eq. (5)] using all treatments.

concentration increased further. Although the general patterns were similar among species, the magnitude of $\mathrm{CR}$, algal concentration showing maximum $\mathrm{CR}$, and the maximum $\mathrm{CR}$ value differed greatly.

The parameter a estimated from fitting equation (2) indicates the magnitude of $\mathrm{CR}$ for each food species. This value for RTDs ranged from 1.3 to 53.4 (Table 2 ), which was lower than that for the standard food (78.8). The highest a value among RTDs was found for A. carterae, which was $67 \%$ of I. galbana. But the lowest a value for G. catenatum was only $1.6 \%$ of $I$. galbana. Among RTDs, A. carterae, L. polyedrum and
$S$. trochoidea showed relatively high a value, while $G$. catenatum, C. polykrikoides and A. affine showed low a value.

The parameter $b$ indicates the inflection point of algal concentration vs. clearance rate curve. When algal concentration is lower than $\mathrm{b}, \mathrm{CR}$ is in increasing phase, while algal concentration is higher than $\mathrm{b}, \mathrm{CR}$ is in decreasing phase. This value gives the information about the relationships between filtration activity of bivalve and quantity (or quality) of food. The parameter $b$ for RTDs ranged from 0.07 to $1.10 \mathrm{mgC} / \mathrm{L}$ (Table 2), which was lower than that for the standard food $(1.91 \mathrm{mgC} / \mathrm{L})$. The highest $\mathrm{b}$ value among RTDs was found for A. carterae, which was $57 \%$ of $I$. galbana. But the lowest a value for $G$. catenatum was only $3 \%$ of I. galbana. Among RTDs, A. carterae, L. polyedrum and S. trochoidea showed relatively high b value, while $G$. catenatum, A. affine, A. catenella and C. polykrikoides showed low b value.

The parameter $\mathrm{C}_{\max }$ indicates the maximum clearance rate of $S$. purpuratus when the algal concentration was b. There was ca. 4-fold difference in the $\mathrm{C}_{\max }$ among RTDs. The highest $\mathrm{C}_{\max }$ was observed when $S$. purpuratus was feeding on $A$. affine, followed by $A$. carterae and A. catenella. $\mathrm{C}_{\max }$ for A. affine $(18.7 \mathrm{~L} / \mathrm{g} / \mathrm{hr})$ and A. carterae $(17.9 \mathrm{~L} / \mathrm{g} / \mathrm{hr})$ were slightly higher than that for the standard food (15.2 L/g/hr) (Table 2). On the other hand, $\mathrm{C}_{\max }$ for chain-forming species, $G$. catenatum and $C$. polykrikoides were relatively lower than that for other species. The lowest $\mathrm{C}_{\max }$ was found when $S$. purpuratus was feeding on C. polykrikoides (4.9 $\mathrm{L} / \mathrm{g} / \mathrm{hr}$ ).

The general patterns of IR with increasing algal concentration for all of 9 RTDs were also similar to that for the standard food (Fig. 5). It increased rapidly at lower range of algal concentration, and then was saturated as algal concentration increased further. However, the intake rate among different RTDs was highly variable.

The parameter $I_{\max }$ estimated from fitting equation (5) indicates the theoretical maximum of intake rate for each food species. There was more than 40-fold difference in the $\mathrm{I}_{\max }$ among RTDs ranging from 1.6 

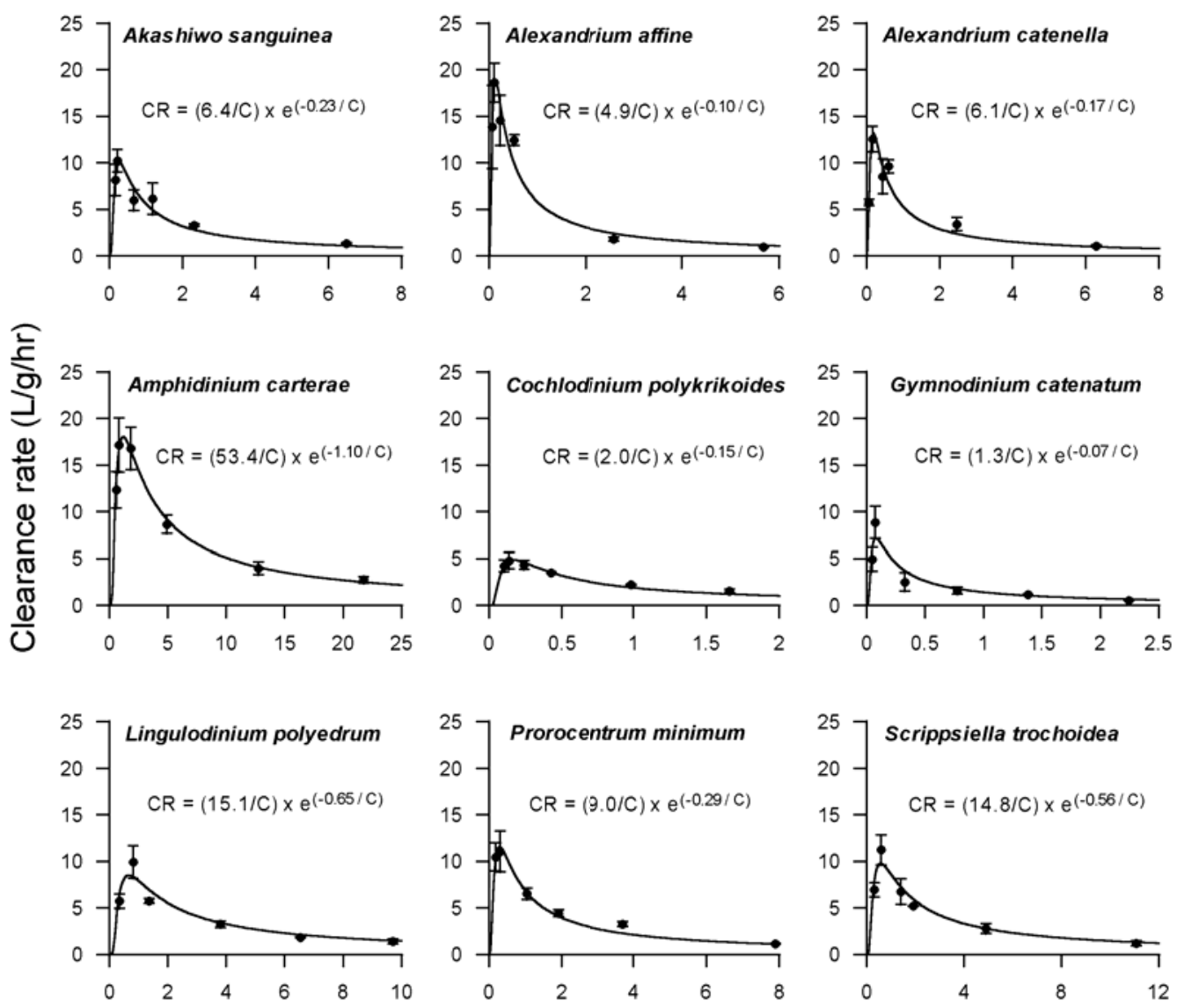

Algal concentration (mgC/L)

Fig. 4. Clearance rate (CR) of juvenile Saxidomus purpuratus as a function of algal concentration (C) when feeding on unialgal diet of each red tide dinoflagellate. Symbol represents treatment mean \pm SE. Curves were fitted by an exponential equation [eq. (2)] using all treatments.

Table 2. Feeding parameters of juvenile Saxidomus purpuratus when feeding on unialgal diet of either the standard food (Isochrysis galbana) or one of the red tide dinoflagellate. Parameters are a (magnitude of overall clearance rate), b (algal concentration at $\mathrm{C}_{\max }, \mathrm{mgC} / \mathrm{L}$ ) $\mathrm{C}_{\max }$ (maximum clearance rate, $\mathrm{L} / \mathrm{g} / \mathrm{hr}$ ), $I_{\max }$ (maximum intake rate, $\mathrm{mgC} / \mathrm{g} / \mathrm{hr}$ ), and $\mathrm{K}_{\mathrm{IR}}$ (algal concentration when the intake rate is $1 / 2$ of $\left.I_{\max }, \mathrm{mgC} / \mathrm{L}\right)$.

\begin{tabular}{lrrrrr}
\hline \multicolumn{1}{c}{ Species } & $\mathrm{a}$ & $\mathrm{b}$ & $\mathrm{C}_{\max }$ & $\mathrm{I}_{\max }$ & $\mathrm{K}_{\mathrm{IR}}$ \\
\hline Isochrysis galbana & 78.8 & 1.91 & 15.2 & 108.1 & 4.37 \\
Akashiwo sanguinea & 6.4 & 0.23 & 10.0 & 10.1 & 0.80 \\
Alexandrium affine & 4.9 & 0.10 & 18.7 & 5.9 & 0.16 \\
Alexandrium catenella & 6.1 & 0.17 & 13.1 & 8.4 & 0.42 \\
Amphidinium carterae & 53.4 & 1.10 & 17.9 & 64.8 & 2.75 \\
Cochlodinium polykrikoides & 2.0 & 0.15 & 4.9 & 3.5 & 0.59 \\
Gymnodinium catenatum & 1.3 & 0.07 & 7.1 & 1.6 & 0.20 \\
Lingulodinium polyedrum & 15.1 & 0.65 & 8.5 & 15.1 & 1.11 \\
Prorocentrum minimum & 9.0 & 0.29 & 11.6 & 11.7 & 0.72 \\
Scrippsiella trochoidea & 14.8 & 0.56 & 9.8 & 14.9 & 0.92 \\
\hline
\end{tabular}



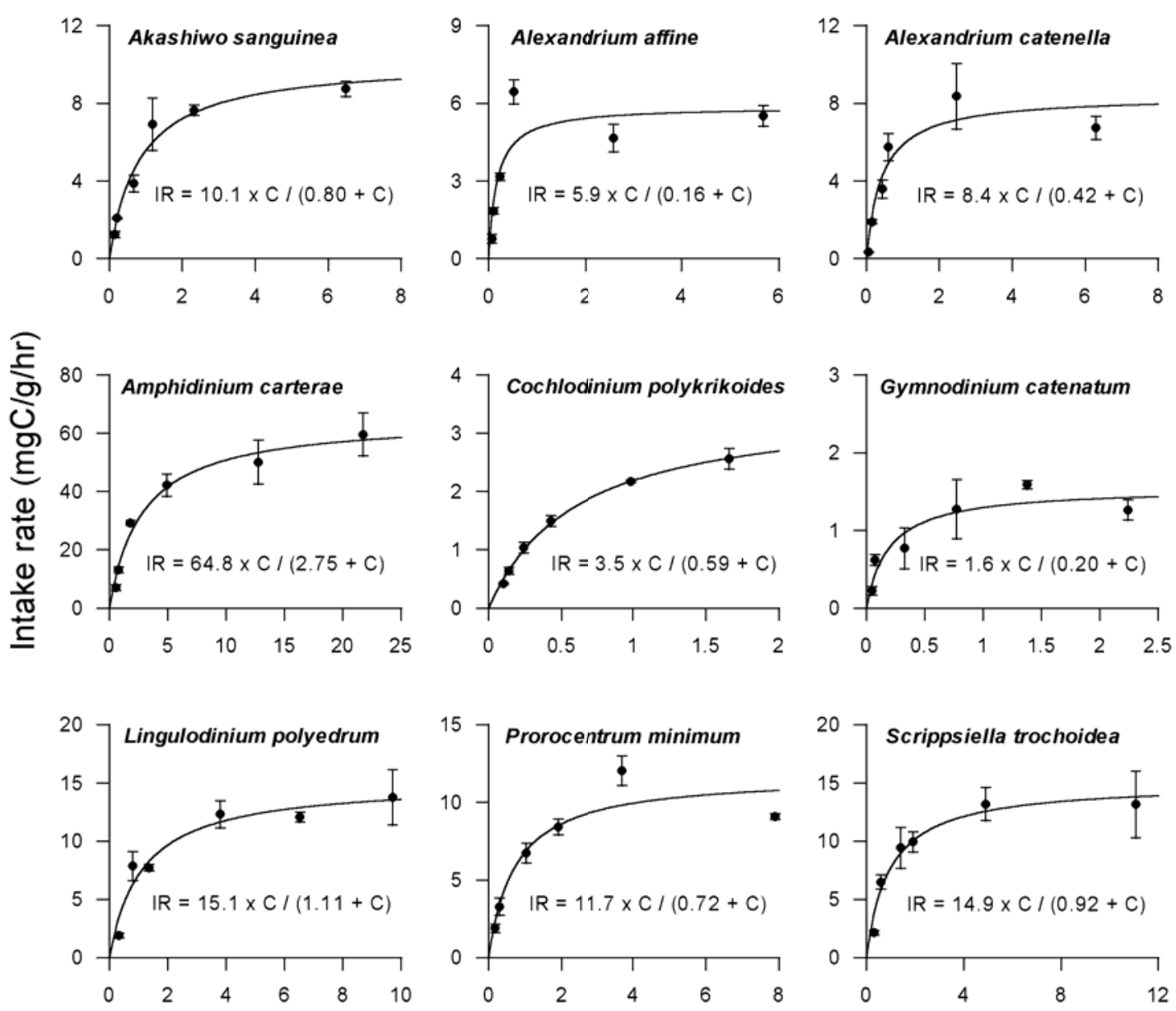

Algal concentration ( $\mathrm{mgC} / \mathrm{L}$ )

Fig. 5. Intake rate (IR) of juvenile Saxidomus purpuratus as a function of algal concentration (C) when feeding on unialgal diet of each red tide dinoflagellate. Symbol represents treatment mean \pm SE. Curves were fitted by the Michaelis-Menten equation [eq. (5)] using all treatments.

to $64.8 \mathrm{mgC} / \mathrm{g} / \mathrm{hr}$ (Table 2), which was lower than that for the standard food $(108.1 \mathrm{mgC} / \mathrm{g} / \mathrm{hr})$. The highest $\mathrm{I}_{\max }$ among RTDs was found for A. carterae (64.8 $\mathrm{mgC} / \mathrm{g} / \mathrm{hr}$ ), which was $59 \%$ of I. galbana. But the lowest $\mathrm{I}_{\max }$ for $G$. catenatum $(1.6 \mathrm{mgC} / \mathrm{g} / \mathrm{hr})$ was only $1.5 \%$ of $I$. galbana. Among RTDs, A. carterae, $L$. polyedrum and $S$. trochoidea showed relatively high $\mathrm{I}_{\max }$, while G. catenatum, C. polykrikoides and A. affine showed low $\mathrm{I}_{\max }$. Except for A. carterae, the $\mathrm{I}_{\max }$ value for other RTDs were less than $14 \%$ of $I$. galbana.

Since there were similarities among estimated parameters from fitting equations (2) and (5), correlation analyses were performed to know whether there are inter-relationships among feeding parameters of $S$. purpuratus. Among parameters from clearance rate function, there was a strong correlation between parameters a and $\mathrm{b}(\mathrm{r}=0.941, \mathrm{p}<0.01)$, while there was no correlation between these two parameters and $\mathrm{C}_{\max }(\mathrm{r}=0.535, \mathrm{p}<0.01$ and $\mathrm{r}=$ $0.336, \mathrm{p}<0.01$ for a vs. $\mathrm{C}_{\max }$, and $\mathrm{b}$ vs. $\mathrm{C}_{\max }$, respectively) (Table 3). From intake rate function, there was a strong correlation between $\mathrm{I}_{\max }$ and $\mathrm{K}_{\mathrm{IR}}(\mathrm{r}$ $=0.971, \mathrm{p}<0.01)$. Moreover, parameters from different functions also showed strong correlations (a vs. $I_{\max }, b$ vs. $I_{\max }$, a vs. $K_{I R}, b$ vs. $K_{I R}, p<0.01$ for all cases). This indicates that parameter $a, b, I_{\max }, K_{I R}$ are inter-related, so that one of these four parameters 
Table 3. Pearson's correlation coefficients among feeding parameters of juvenile Saxidomus purpuratus when feeding on unialgal diet of red tide dinoflagellates. Values with asterisks indicate that correlation is significant $(p<0.01)$.

\begin{tabular}{cccccc}
\hline & $\mathrm{a}$ & $\mathrm{b}$ & $\mathrm{C}_{\max }$ & $\mathrm{I}_{\max }$ & $\mathrm{K}_{\mathrm{IR}}$ \\
\hline $\mathrm{a}$ & 1.000 & & & \\
$\mathrm{~b}$ & $0.941^{* *}$ & 1.000 & & & \\
$\mathrm{C}_{\max }$ & 0.525 & 0.336 & 1.000 & & \\
$\mathrm{I}_{\max }$ & $0.995^{* *}$ & $0.911^{* *}$ & 0.540 & 1.000 & 1.000 \\
$\mathrm{~K}_{\mathrm{IR}}$ & $0.972^{* *}$ & $0.951^{* *}$ & 0.358 & $0.971^{* *}$ & 1.000 \\
\hline
\end{tabular}

can sufficiently represent and explain the trends of other parameters. In this study, $I_{\max }$ was selected as a representative parameter for further discussion, because it has the physiological information on maximum potential of intake rate of $S$. purpuratus for a given food species. Meanwhile $\mathrm{C}_{\max }$ showed no correlation with other parameters, so it can be treated as an independent parameter.

Sprung and Ross (1988) suggested the ratio between maximum intake rate and maximum clearance rate as the "incipient limiting concentration (ILC)" around which the major change in functional responses occur. The ILC also provides the information on how much a bivalve can tolerate with increasing food concentration. In our data, the ILC concentration for RTDs lied between 0.23 and 3.62 $\mathrm{mgC} / \mathrm{L}$ which is ca. $3.2-51 \%$ of that for I. galbana
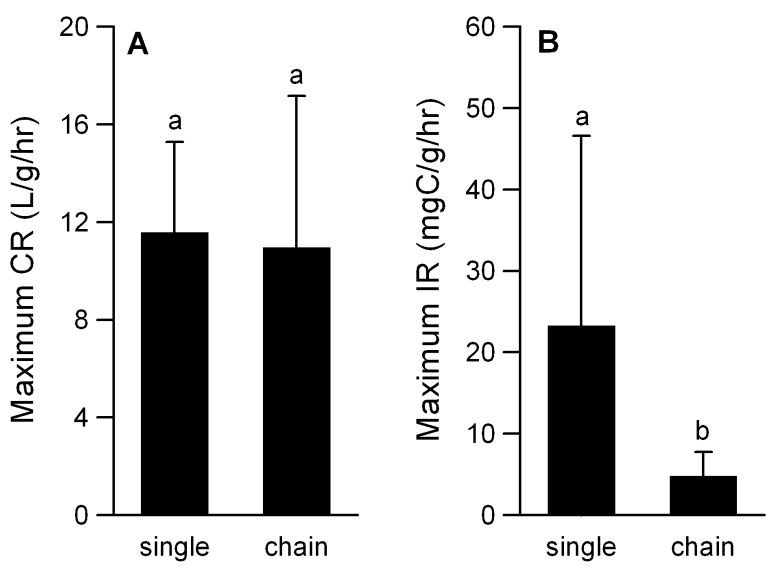

Fig. 6. Comparison of mean of maximum $\mathrm{CR}$ and maximum IR of Saxidomus purpuratus between single-celled and chain-forming red-tide dinoflagellates as food species.
$(7.11 \mathrm{mgC} / \mathrm{L})$. It is regarded that better food has higher ILC. The ILC for RTDs in this study can be arranged as (in descending order); A. carterae $>L$. polyedrum $>S$. trochoidea $>A$. sanguinea $>P$. minimum $>$ C. polykrikoides $>$ A. catenella $>A$. affine $>$ G. catenatum. Generally, single celled RTDs showed higher ILC, while chain-forming RTDs showed lower ILC.

\section{Factors affecting feeding parameters}

Fig. 6 shows the relationships between cell size (carbon content) of RTDs and feeding paramaters $\left(\mathrm{C}_{\max }\right.$ and $\left.\mathrm{I}_{\max }\right)$ of $S$. purpuratus. Since there was a strong correlation between the diameter and carbon content of RTDs $(r=0.976, p<0.01)$, we used the carbon content as a index of cell size. Although $\mathrm{C}_{\max }$ and $\mathrm{I}_{\max }$ apparently seem to decrease with increasing carbon content $\left(\mathrm{r}=-0.439\right.$ for $\mathrm{C}_{\max }$ and -0.347 for $\mathrm{I}_{\max }$ ), there were no statistical significances in both cases ( $\mathrm{p}=0.239$ and 0.360 , respectively). A. affine, $A$. catenella, S. trochoidea, and C. polykrikoides were quite similar in cell size (23 - $25 \mu \mathrm{m}$ in ESD), but $\mathrm{C}_{\max }$ differed greatly (Fig. 6A). There was a 3.8 fold difference between $A$. affine and $C$. polykrikoides. This pattern was also found in $\mathrm{I}_{\max }$. A. carterae and $P$. minimum were similar in cell size $(13-16 \mu \mathrm{m}$ in ESD), but there was a 5.5 fold difference in $I_{\max }$ between two species (Fig. 6B). On the other hand, we could find RTDs with different cell size showing similar $\mathrm{I}_{\max } . \quad$ L. polyedrum $(37.9 \mu \mathrm{m})$ and $S$. trochoidea $(25.1 \mu \mathrm{m})$ were 2- and 3-times larger than P. minimum $(12.9 \mu \mathrm{m})$, but differences in $\mathrm{I}_{\max }$ of 

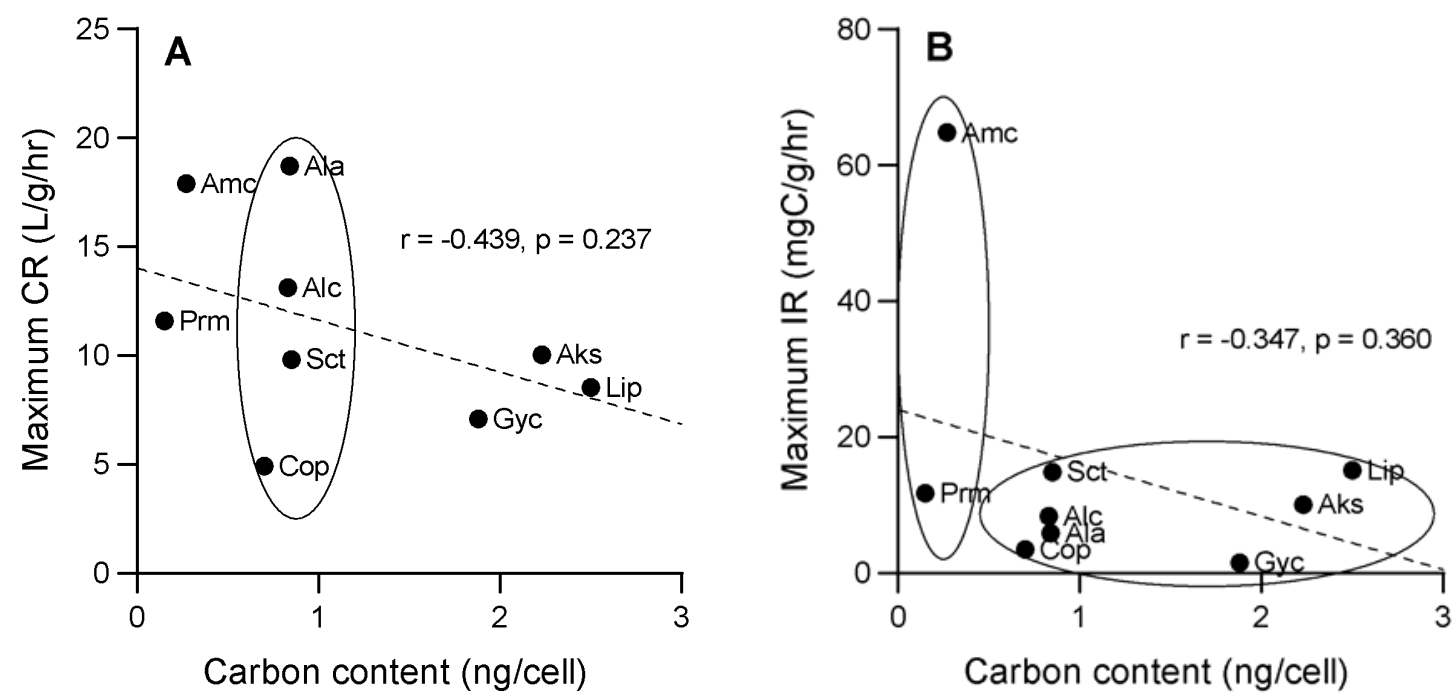

Fig. 7. Relationships between the size (carbon content) of red-tide dinoflagellates and the feeding parameters of Saxidomus purpuratus (A: maximum CR, B: maximum IR, Ala: Alexandrium affine, Amc: Amphidinium carterae, Alc: Alexandrium catenella, Prm: Prorocentrum minimum, Aks: Akashiwo sanguinea, Sct: Scrippsiella trochoidea, Lip: Lingulodinium polyedrum, Gyc: Gymnodinium catenatum, Cop: Cochlodinium polykrikoides).

these three species were less than 1.3 fold (Fig 6B).

Sprung and Rose (1988) reported the relationship between the size of food particle and the clearance rate of bivalve. They observed that the clearance rate of Dreissena polymorpha was nearly zero when food particle was less then $0.7 \mu \mathrm{m}$, increased as particle size increased within the range of 0.7 to $5 \mathrm{~mm}$, and nearly constant when food particle was in the range of 5-35 $\mu \mathrm{m}$. The size range of RTDs in this study is 13-38 $\mu \mathrm{m}$, which is overlapping the last category of Sprung and Rose (1988), indicating that size effect on clearance rate is negligible. Shumway et al. (1997) measured the clearance rate of 3 juvenile scallops with different size of food particles, and reported that there was optimal range in the size of food particle and the range was different for different bivalve species. The size ranges of food particles showing the highest clearance rate of Patinopecten yessoensis and Placopecten magellanicus were 3-5 $\mu \mathrm{m}$ and $3-8 \mu \mathrm{m}$, respectively. They also reported that the clearance rate of $P$. magellanicus decreased when food particle was larger than $8 \mu \mathrm{m}$. According to them, all the RTDs in this study were much larger than the threshold cell size so that the lower clearance rate than that for I. galbana $(4.5 \mu \mathrm{m})$ could be explained.

Fig. 7 compares the mean of feeding parameters $\left(\mathrm{C}_{\max }\right.$ and $\left.\mathrm{I}_{\max }\right)$ between single celled RTDs and chain-forming RTDs. There was no significant difference in $\mathrm{C}_{\max }$ between single-celled and chain-forming RTDs $(p=0.859)$. However, significant difference was found in $\mathrm{I}_{\max }$ between two groups ( $\mathrm{p}<$ 0.05 ). When we arrange the RTDs in ascending order of $I_{\max }$, chain-forming 4 species lied from the first to fourth rank. Moreover, it seemed that the length of chain also affected the $I_{\max }$. The lowest $I_{\max }$ was found in $G$. catenatum that forms 8 to 16 -celled chains, the next $C$. polykrikoides that forms 4 to 8-celled chains, and then followed by $A$. affine and A. catenella those form 2-celled chains.

Lee et al. (2003) observed similar results from estimating the feeding parameters of Glauconome chinensis feeding on 3 kinds of RTDs. They reported that there was more than 10 fold difference in $I_{\max }$ of G. chinensis between single-celled RTD (S. trochoidea) and chain-forming RTD (C. polykrikoides). The results from this study for $S$. purpuratus are in good 

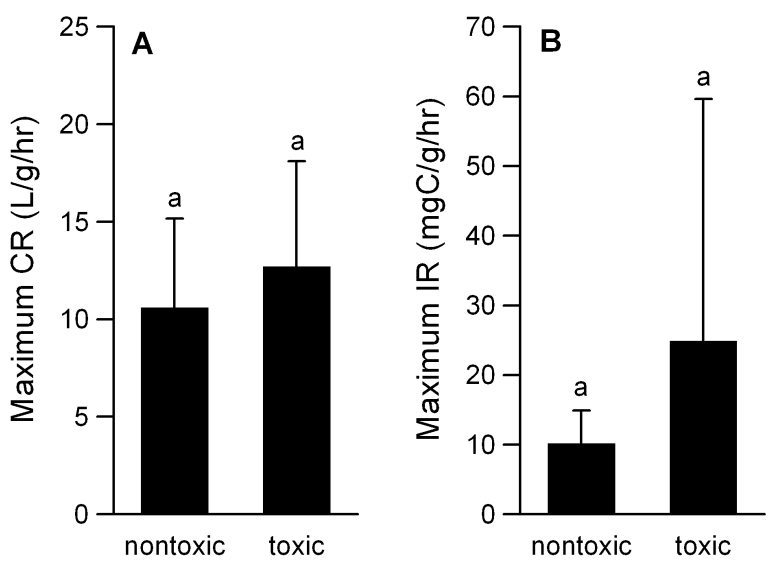

Fig. 8. Comparison of mean of maximum $\mathrm{CR}$ and maximum IR of Saxidomus purpuratus between nontoxic and toxic red-tide dinoflagellates as food species.

accordance with Lee et al. (2003).

Fig. 8 compares the mean of feeding parameters $\left(\mathrm{C}_{\max }\right.$ and $\left.\mathrm{I}_{\max }\right)$ between nontoxic RTDs and toxic RTDs. There were no significant differences in both $\mathrm{C}_{\max }$ and $\mathrm{I}_{\max }$ between nontoxic and toxic RTDs. Although not statistically significant, both parameters for toxic RTDs were numerically higher than nontoxic RTDs. Moreover, a toxic dinoflagellate, A. carterae recorded the highest $I_{\max }$ among RTDs (see Table 2). Higher mean $\mathrm{C}_{\max }$ and $\mathrm{I}_{\max }$ are mainly contributed by those of A. carterae. This indicates that the toxicity did not affect the feeding activity of $S$. purpuratus.

It is noticeable that the highest $I_{\max }$ was found in toxic A. carterae. This species is known to produce hemolytic compounds (Nayak et al., 1997). Though not reported in Korean coastal waters, A. carterae is found in Japan, New Zealand, Australia, Canada, UK, and USA (Anderson, et al., 1995). Red tides dominated by $A$. carterae killed fishes (Yasumoto, 1990). The toxicity was reported as $1 \mathrm{MU} / 1.3 \times 10^{8}$ cells (Jeong et al., 2001). Nevertheless this species turned out to be the most favorable food among RTDs in this study. Lee (2003) studied the effects of RTDs on the survival and growth of larvae of Mytilus galloprovincialis and found no lethal effect of $A$. carterae, although it showed significant inhibition on growth. Jeong et al. (2001) also reported that the heterotrophic dinoflagellate Oxyrrhis marina was able to grow well on $A$. carterae. Therefore, toxicity of
RTDs on vertebrates maybe did not act as the same on invertebrates.

Whether a bivalve has preference between nontoxic and toxic algal food is not generalized so far. Matsuyama et al. (1997) reported that the clearance rate of Mytilus galloprovincialis fed on toxic dinoflagellate (Heterocapsa circularisquama) was significantly lower than those on nontoxic dinoflagellates (S. trochoidea and Heterocapsa triquetra). However, there are other reports that clearance rate does not differ between toxic and nontoxic algal species. Li and Wang (2001) reported that Perna viridis and Ruditapes philippinarum showed no differences in clearance rates between toxic and nontoxic strains of Alexandrium tamarense. Li et al. (2001) also reported that Clamys nobilis and $R$. philippinarum could not distinguish between toxic dinoflagellate (A. tamarense) and nontoxic diatom (Thalassiosira pseudonana). Therefore, toxic dinoflagellates are not always recognized as poor food source by bivalves. Whether the feeding activity is affected by the presence or absence of toxicity of algae seems to be species-specific (of bivalve). S. purpuratus seems to belong to the group that has no preference between toxic and nontoxic RTDs. Therefore, the most important characteristic of RTD as a factor affecting the feeding rate of $S$. purpuratus is life form, not size or toxicity of RTD species.

\section{ACKNOWLEDGEMENTS}

We thank Dr. Yong-Suk Choi, Dr. Jae-Yoon Song, and Mrs. Song-Hee You for technical support. This study was supported by the Korea Research Council of Public Science and Technology (BSPG 361-00).

\section{REFERENCES}

Anderson, R.A., Blackburn, S.I., Taylor, F.J.R., and Tomas, C.R. (1995) Algal culture collections and toxic algal strains. In: Manual on Harmful Marine Microalgae (ed. by Hallegraeff, G.M., Anderson, D.M., and Cembella, A.D.). IOC Manuals and Guides No. 33. UNESCO, pp. 489-531.

Båmstedt, U., Gifford, D.J., Irigoien, X., Atkinson, A., and Roman, M. (2000) Feeding. In: Zooplankton Methology Manual (eds. by Harris, R.P., Wiebe, P.H., Lenz, J., Skjoldal, H.R. and Huntley, M.). pp. 
297-399. Academic Press. London, UK.

Bayne, B.L., Thompson, R.J. and Widdows, J. (1976) Physiology: I. In: Bayne, B.L. (ed.) Marine mussels: their ecology and physiology. Cambridge University Press. Cambridge, London, NewYork, Melbourne. pp. 121-206.

Choe, B. R., Park, M. S., Jeon, L. G., Park S. R. and Kim, H. T. (1999) Commercial molluscs from the freshwater and continental shelf in Korea. National Fisheries Research and Development Institute. Kudeok Press, Pusan. 197 pp. (in Korean).

Coughlan, J. (1969) The estimation of filtering rate from the clearance of suspensions. Marine Biology, 2: 356-358.

Coutteau, P., Curé, K. and Sorgeloos, P. (1994) Effect of algal ration on feeding and growth of juvenile Manila clam Tapes philippinarum (Adams and Reeve). Journal of Shellfish Research, 13: 47-55.

Crawley, M.J. (1975) The numerical response of insect predators to changes in prey density. Journal of Animal Ecology, 44: 877-892.

ECOHAB (1995) The Ecology and Oceanography of Harmful Algal Blooms. A National Research Agenda. Woods Hole Oceanographic Institute. Woods Hole. pp. 1-66.

Foster-Smith, R.L. (1975) The effect of concentration of suspension on the filtration rates and pseudofecal production of Mytilus edulis L., Cerastoderma edule (L.) and Venerupis pullastra. Journal of Experimental Marine Biology and Ecology, 17: 1-22.

Guillard, R.R.L. and Ryther, J.H. (1962) Studies of marine planktonic diatoms. I. Cyclotella nana Hustedt and Detonula confervacea (Cleve) Grun. Canadian Journal of Microbiology, 8: 229-239.

Jeong, H.J., Kang, H., Shim, J.H., Park, J.K., Kim, J.S., Song, J.Y., and Choi, H.-J. (2001) Interactions among the toxic dinoflagellate Amphidinium carterae, the heterotrophic dinoflagellate Oxyrrhis marina, and the calanoid copepods Acartia spp. Marine Ecology Progress Series, 218: 77-86.

Lee, C.-H., Choi, Y.-S., Bang, J.-D. and Jo, S.-G. (2002) Feeding of juvenile purple Washington clam, Saxidomus purpuratus (Sowerby): Effects of algal concentration and temperature. Journal of Aquaculture, 15(4): 253-260.

Lee, C.-H., 2003. Effects of the red tide and toxic dinoflagellates on the survival and growth of larvae of the mussel, Mytilus galloprovincialis. Korean Journal of Malacology, 19(1):25-32

Lee, C.-H., Song, J. Y. and Chung, E.-Y. (2003) Filtration of red tide dinoflagellates by an intertidal bivalve Glauconome chinensis Gray: An implication for the potentials of bivalves in tidal flats. Journal of Fisheries Science and Technology, 6(2): 66-73.
Lesser, M.P. and Shumway, S.E. (1993) Effects of toxic dinoflagellates on clearance rates and survival in juvenile bivalve molluscs. Journal of Shellfish Research, 12: 377-381.

Li, S.-C. and Wang, W.-X. (2001) Radiotracer studies on the feeding of two marine bivalves on the toxic and nontoxic dinoflagellate Alexandrium tamarense. Journal of Experimental Marine Biology and Ecology, 263:65-75.

Luckenbach, M.W., Sellner, K.G., Shumway, S.E., and Greene, K. (1993) Effects of two bloom-forming dinoflagellates, Prorocentrum minimum and Gyrodinium uncatenum, on the growth and survival of the eastern oyster, Crassostrea virginica (Gmelin 1791). Journal of Shellfish Research, 12: 411-415.

Matsuyama, Y., Uchida, T. and Honjo, T. (1997) Toxic effects of the dinoflagellate Heterocapsa circularisquama on clearance rate of the blue mussel Mytilus galloprovincialis. Marine Ecology Progress Series, 146:73-80.

Nayak, B.B., Karunasagar, I., Karunasagar, I. (1997) Influence of bacteria on growth and hemolysin production by marine dinoflagellate Amphidinium carterae. Marine Biology, 130(1): 35-39.

Nielsen, M.V. and Strømgren, T. (1991) Shell growth response of mussels (Mytilus edulis) exposed to toxic microalgae. Marine Biology, 108: 263-267.

Riisgård, H.L. (1988) Feeding rates in hard clam (Mercenaria mercenaria) veliger larvae as a function of algal (Isochrysis galbana) concentration. Journal of Shellfish Research, 7: 377-380.

Shumway, S. E., Cucci, T. L., Lesser, M. P., Bourne, N. and Bunting, B. (1997) Particle clearance and selection in three species of juvenile scallops. Aquaculture International, 5:89-99.

Sprung, M. and Rose, U. (1988) Influence of food size and food quality on the feeding of the mussel Dreissena polymorpha. Oecologia, 77:526-532.

Strathmann, R.R. (1967) Estimating the organic carbon content of phytoplankton from cell volume or plasma volume. Limnology and Oceanography, 12: 411-418.

Widdows, J., Moore, M.N., Lowe, D.M., and Salkeld, P.N. (1979) Some effects of a dinoflagellate bloom (Gyrodinium aureolum) on the mussel Mytilus edulis. Journal of the Marine Biological Association of the United Kingdom, 59: 522-52.

Yasumoto, T. (1990) Marine microorganism toxins - An overview. In: Toxic Marine Phytoplankton (ed. by Graneli, E., Sundstrøm, B., Edler, L., and Anderson, D.M.). Elsevier Science Publ., New York, pp. 3-8.

Zar, J.H. (1984) Biostatistical Analysis, Second Edition. 718 pp. Prentice-Hall International, Inc., Engelwood Cliffs, NJ. 